Research Article

\title{
EFFECT OF ENERGY INPUT ON WEAR PERFORMANCE OF BORON COATING MADE WITH PTA
}

\begin{abstract}
Musa KILIÇ
It is inevitable that wear on the surfaces occur when especially metal surfaces contact each other. One of the most crucial problems among surface machining is wear problem. In this study, surface of $316 \mathrm{~L}$ stainless steel was coated with boron via plasma arc method and 160, 165 and 170 current values were utilized as welding parameters.

The effect of the energy input on microstructure and on the abrasion resistance of the hard structures formed in the coating region was investigated.

It was determined from optical microscope and SEM analysis that the coating area consisted of branched and leaf-shaped dendritics; and eutectic structures were formed between these dendritics. As a result of EDX taken from coated region, $\mathrm{Fe}, \mathrm{B}$ and $\mathrm{Cr}$ elements were found. After wear test, low mass loss was determined in samples coated with Boron 2 and it is clear that coating os Boron on 316 L stainless steel substrate is increased wear resistance. While the highest weight loss was occurred in 316 L satinless steel with $45 \mathrm{mg}$ and the lowest weight loss was obtained from Boron 2 sample with $27 \mathrm{mg}$.
\end{abstract}

Key Words: PTA, Boron, Abrasive resistance, Coating

\section{Introduction}

Wear is one of the problems which is not wanted in industry as a consequence of demages that it leads to in engineering processes in terms of cost, labor and time when the metals contact to each other.

According to their usage places, the tribology properties of metals can be improved by using surface coating methods in order to eliminate the damages such as fatigue, friction and wear occurring in metals [1-2].

As surface coating methods, hard filling processes such as plasm transferred arc welding (PTA) and gas tungsten arc welding (GTAW) were used with the help of thermal sparying methods such as high velocity oxy fuel (HVOF), atmospheric plasma spraying (APS) and flame sparying(FS) [3-7].

\footnotetext{
1 Department of Machinery and Manufacturing Engineering, University of Batman, Batman, Turkey, (musa.kilic@batman.edu.tr) Dhttps://orcid.org/0000-0002-5808-6917
} 
PTA coating method is a preferred method because it is cheap and feasible. In addition, PTA method has attracted the attention of researchers in recent years due to its high welding speed, well penetration depth and good arc stability, as well as its wear-corrosion resistance and improved fatigue strength[811]. In particular, in this method, besides the wide range of materials, the performance of the material surfaces can be greatly improved by low dilution and deterioration between the hard filler layer formed on the coated surfaces and the substrate material [12-16]. Plasma transferred arc (PTA) technique provides strong metallurgical bond formed between the coating and substrate, low porosity, high energy conversion efficiency, high precipitation rate, low heat input [17].

Since the materials are melted in PTA coatings, the melting temperature of the metal to be formed with the base material should be approximately the same or lower than the base metal. Otherwise, the plasma arc does not melt or partially melt the material to be coated while melting the base metal at high temperatures. In this case, since a good diffusion cannot be achieved, the coating layer cannot be formed completely [18].

Q.Y. Hou et al. [19] investigated the effects of molybdenum on the microstructure and wear resistance of nickel-based alloy coatings with PTA method and established that the wear resistance increased by $47.2 \%$.

Y. F. Liu et al. [20] investigated the microstructure and non-lubricated shear wear properties of TIC reinforced composite coating performed by PTA method; and obtained the result of high surface hardness and non-lubricated wear resistance of the composite coating.

L. Bourithis et al. [21] applied boroning process to AISI 1018 steel with the help of PTA coating method and obtained coatings in thicknesses ranging from 1 to $1.5 \mathrm{~mm}$ and in hardness ranging from 400 to $1600 \mathrm{HV}$. In the examination, they observed that the wear was quite low.

R. Iakovu et al. [22] showed that hardness values were established between 1000-1300 HV as a result of coating, and that tool steels were successfully coated with boron by using PTA coating method. They determined that the boroned surface contained austenitic and martensitic mixtures together with the $\mathrm{Fe}_{2} \mathrm{~B}$-type boride layer, and that some cracks were observed in the austenitic regions and these cracks did not have any critical effects on slip wear.

L. Bourithis and G. Papadimitrou [23] achieved successful coatings in boron and $\mathrm{CrB}_{2}$ coating work of the plain carbon steel surface with PTA coating method. As a result of the study, they stated that the wear rates were low in both coatings, and they obtained hardness between 1000-1300 HV in boron coatings and $900 \mathrm{HV}$ hardness in coating made with $\mathrm{CrB}_{2}$ powder.

In this method, since the arc temperature rises to high temperatures, the surface of metal and metal alloys with high melting temperature is applied by using many coating powders and combinations of these powders. Thanks to its high coating thickness and high energy density, PTA hard fill coating is widely used in sectors such as defense industry, aircraft industry, machinery and manufacturing, medicine, automotive industry [24-26].

Boron and boron-derived products with different uses have also been widely used in the surface hardening process of steels in the industry [27].

Boron surface coating can be applied to tempered steels, tool steels, stainless steels, cast steels, cast irons, non-ferrous metals and alloys such as sintered metal powders, nickel, cobalt, molybdenum and titanium [28-29].

The high hardness of the boride layer and the low friction coefficient contribute to the increase of wear resistance[22, 29]. 
Boroning can increase the service life of the steels by increasing the wear resistance, corrosionerosion resistance and microhardness $[\mathbf{3 0 - 3 1}]$. The surface coating process with boroning method is a method that is used a lot in the industry, and it brings the surface of the applied material to very high hardness values. The hardness of the boron layer varies between 1800-2100 HV and can reach up to $2400 \mathrm{HV}$ in high alloy steels $[\mathbf{2 2}, \mathbf{3 2}]$. In addition, boron coating contributes to increase the breaking and flowing fatigue and corrosion fatigue resistance of metals [33-34].

In this study, surface of $316 \mathrm{~L}$ stainless steel was coated with boron element by plasma transfer arc method (PTA). Coating morphology was characterized by optical microscope and SEM-EDX. The effect of energy in put on the hard structures which formed after coating on substrate was examined by wear test and under the load of 5N, 10N and 20N for ASTM G99 standards with the help of a pin on disc method.The mass loss of the wear zone after the wear process was characterized by microstructure.

\section{Materials and Method}

In this study, surface coating was applied to the surface of AISI 316 L steel by using elemental boron powder with PTA. The chemical composition of boron powder and substrate materials are given in Table 1 and Table 2, respectively. The boron used in the coating process had a grain size of $1 \mu \mathrm{m}$. Table 2 shows the chemical composition of boron powder and the properties of the powder.

Tablo 1: Boron chemical composition

$\begin{array}{clllll} & \begin{array}{l}\text { Purity } \\ \text { Average }\end{array} & \begin{array}{l}\text { Melting } \\ \text { particle } \\ \text { size }\end{array} & \begin{array}{l}\text { Temp. } \\ (\%)\end{array} & \begin{array}{l}\text { Density } \\ \left(\mathrm{gr} / \mathrm{cm}^{3}\right)\end{array} & \begin{array}{l}\text { Molecular } \\ \text { weight } \\ (\mathrm{gr} / \mathrm{mol})\end{array} \\ \text { Boron } & 96.21 & <1.5 \mu \mathrm{m} & 2076 & 2.34 & 10.81\end{array}$

Table 2: AISI 316L stainless steel chemical composition

$\begin{array}{llllllll}\mathrm{Cr} & \mathrm{C} & \mathrm{S} & \mathrm{Ni} & \mathrm{Si} & \mathrm{Mn} & \mathrm{Mo} & \mathrm{P} \\ 18.0 & 0,03 & 0,03 & 14.0 & 0,75 & 2.0 & 3.0 & 0.045\end{array}$

Before coating, the surface of AISI 316L stainless steel, which would be used as substrate material, was cleaned with a lathe to remove dirt and oxides. As shown in Figure 1a, $10 \mathrm{~mm}$ width and $3 \mathrm{~mm}$ deep grooves were opened on the surface of AISI $316 \mathrm{~L}$ stainless steel with the help of milling machine so that dust can be deposited on the substrate after surface cleaning process.
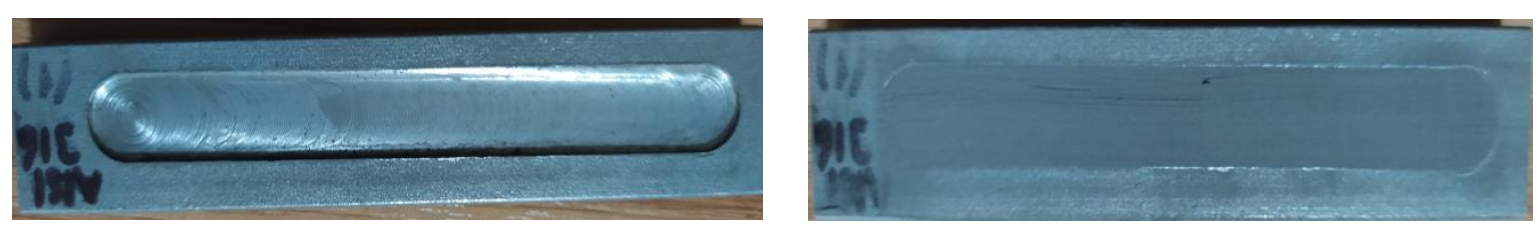

Figure 1: (a) AISI 304 satinless steel substrate, (b) Boron powder laid base 
After the grooving process was completed, the samples were then cleaned by washing in acetone bath to remove dirt and debris.

Into the groove opened sample, the boron element was deposited in the substrate after soaked with polyvinyl alcohol in an atmosphere of argon gas Figure 1b. Samples were placed in the oven at $30^{\circ} \mathrm{C}$ and dried so that the wetting agent would be removed from coating zone before coating with PTA. The main purpose of wetting the powders with polyvinyl alcohol is prevent flying of boron powder from channel during arc blow.. For the welding parameters(160A, 170A and 180A), only the mechanical impacts provided by the different current values on the coating surface and the interface surface were examined.

After the samples were prepared, coating was performed with plasma arc welding using the parameters given in Table 3. The schematic picture of the plasma source used in the experimental phase and the coating sample produced after the process are given in Figures $2 a$ and $b$.

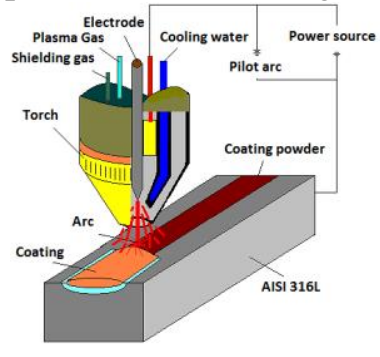

(a)

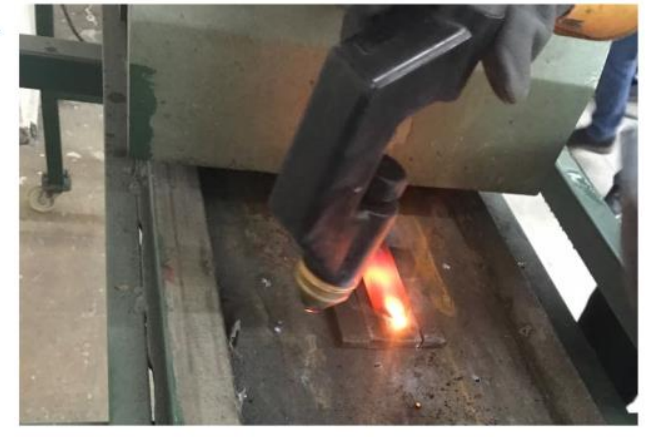

(b)

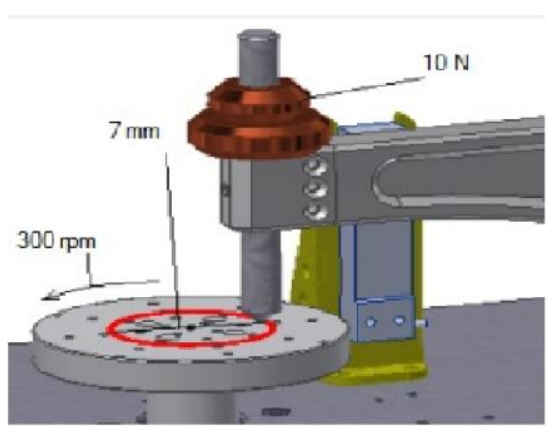

Figure 2: (a)Schematic figure of PTA source and coating process [23] , (b) Sample processed with cooating, (c) Wear device schematic picture

After successful coating process, samples were cut in a precision cutting machine in a perpendicular direction to the coating for wear and microstructure analysis. The samples, of which the cutting process was completed, were subjected to coarse polishing with optical microscope, SiC sandpaper with 240-1200 mesh size for SEM-EDX analysis. In the fine polishing process, the samples were polished with 1 micron diamond paste and broadcloth. In microstructure and SEM-EDX analysis, samples were etched with Nital solution before internal structure analysis. Microstructured analysis of the etched samples was carried out with Nicon optical microscope. JSM5600 Brand SEM-EDX device was used for detailed microstructure and elemental analysis.

Table 3: Boron coating process parameters

$\begin{array}{llllll}\begin{array}{l}\text { Sample } \\ \text { No }\end{array} & \begin{array}{l}\text { Setback } \\ \text { Adjustment } \\ (\mathbf{m m})\end{array} & \begin{array}{l}\text { Nozzle } \\ \text { Diameter } \\ (\mathbf{m m})\end{array} & \begin{array}{l}\text { Current } \\ (\mathbf{A})\end{array} & \begin{array}{l}\text { Protectve } \\ \text { Gas }\end{array} & \begin{array}{l}\text { Plasma } \\ \text { Gas }\end{array} \\ \text { Boron-1 } & 0,8 & 2,4 & 160 & 25 & \mathbf{L} / \mathbf{m i n} \\ \text { Boron-2 } & 0,8 & 2,4 & 165 & 25 & 0,5 \\ \text { Boron-3 } & 0,8 & 2,4 & 170 & 25 & 0,5\end{array}$

Samples with coating process were subjected to abrasion using the ASTM G99 standard with the pin-on disk device of Turkyus Podwt, the schematic picture of which is given in Figure 2c. 
The wear parameters were chosen as applied load $10 \mathrm{~N}$, the sliding speed $0.4 \mathrm{~m} / \mathrm{s}$ and the sliding distances $250 \mathrm{~m}, 5000 \mathrm{~m}$ and $1000 \mathrm{~m}$. stalked grit sandpaper was used as abrasive. Mass Losses from the sample after wear were determined by weighing the residue on a balance with a sensitivity of $0.0001 \mathrm{mg}$.

\section{Results and Discussion}

\subsection{Microstructure}

The optical microscope, SEM pictures of the coating layers are shown in Figure $3 \mathrm{a}, \mathrm{c}, \mathrm{d}$ and in Figure $3 b$, the EDS result table in the SEM image.

As seen in Figure 4, the XRD result containing the phase compounds obtained in the coating layer is given.

It was observed that the coating zone did not contain any adverse effects such as cracks and pores. The feed rate and energy inputs used in PTA surface coating process melted the substrate material together with the coating material, resulting in metallurgically bonded coatings [35]. However, with the increasing current value, the increase of energy input increased the melting of the substrate material.

It is estimated that the melting depth has increased in parallel with the increase in the current value and the increase in the melting rate [9].

In the coating process, the tungsten electrode in the plasma arc welding torch was used as heat source. The method allows the formation of a liquid bath with the coating layer and the substrate melting together with the start of the arc. It is based on the rapid solidification of the liquid bath with the advancement of the torch. Fu Liu et al. stated that with the advancement of the torch in the coating process with PTA, the melt at the bottom of the melting pool would result in solidification in the form of a fusion line. They also noted that with the formation of the fusion line, interdiffusion occurred between the coating layer and the substrate, and a high-quality metallurgical bond was formed [2]. Diffusion between the substrate and the coating layer appears to have been successful. As shown in the optical microscope picture, deep lines seen in the substrate region are thought to be traces of rolling. In the coating area, it was determined that dendritic structures were formed intensely together with the eutectic structure.

The diffusion occurring in the solid with the solidification of the liquid bath changes the distribution of the dissolved substrate and the elements of the coating layer. The dendrite formed after solidification causes a minimum soluble content in the arms [36]. Dendrites occurring in the form of primary and secondary arms in metal or alloy elements are the most frequently observed microstructure in solidified metals and other materials. While rapid cooling produces thin dendrites, slow cooling affects the properties of the materials by providing large and coarse dendrites [37-39].

Dendritic structures formed in the form of leafy, cellular and branched shapes at the same time, especially in the region close to the interface and in the coating area, are more clearly seen in SEM pictures given in Figure $3 \mathrm{~b}$. The dendritic arms formed showed a developed perpendicular to the coating layer.

This liquid bath was determined after XRD analysis that substrate elements and coating material formed hard phases such as $\mathrm{FeB}, \mathrm{Fe} 2 \mathrm{~B}$ and $\mathrm{CrB}$ after solidification. 


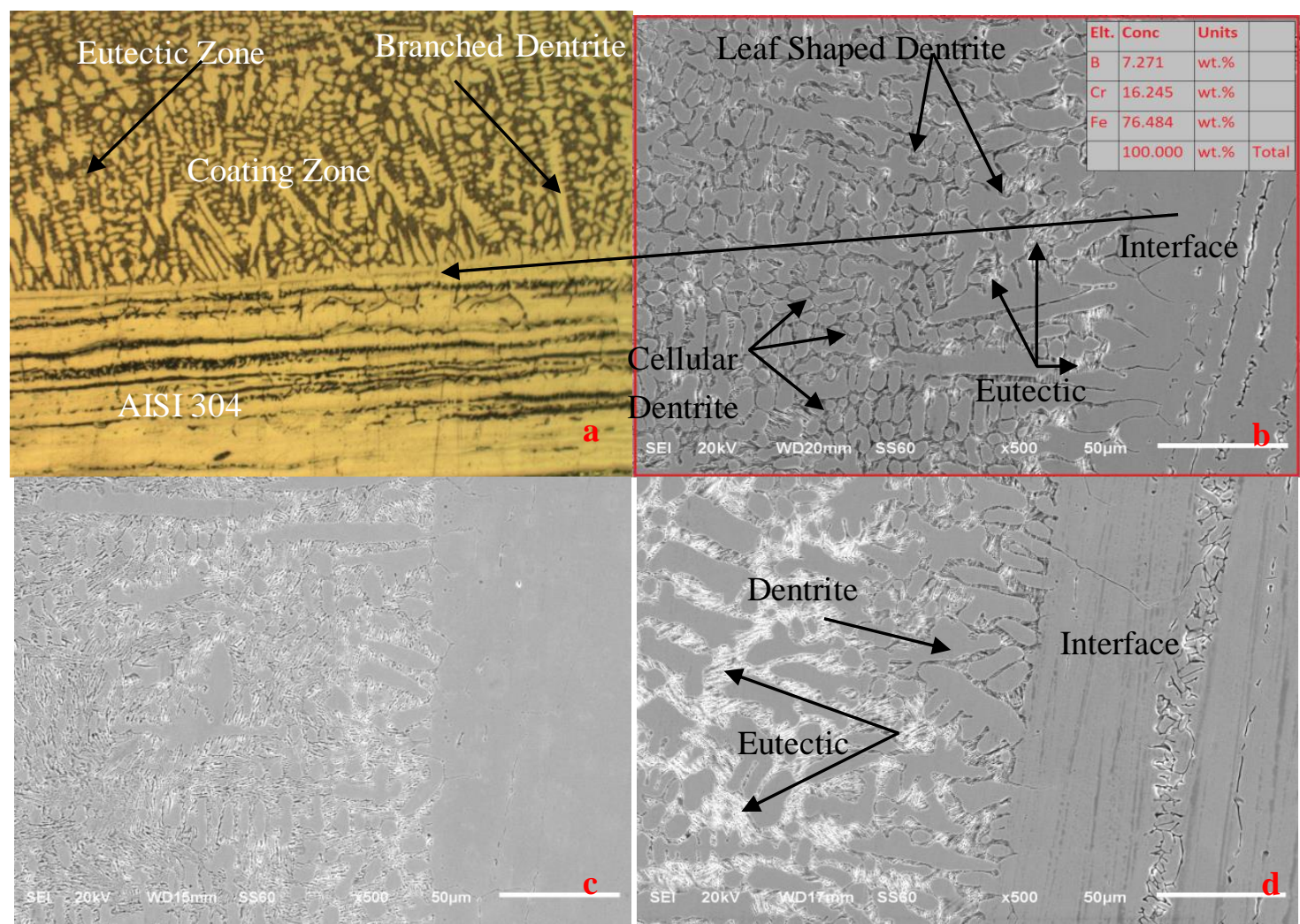

Figure 3: (a) Picture of Optical Microscope, (b) Boronl coating zone SEM picture and EDS table, (c) Boron2 coating zone SEM picture, (d)Boron3 coating zone SEM picture

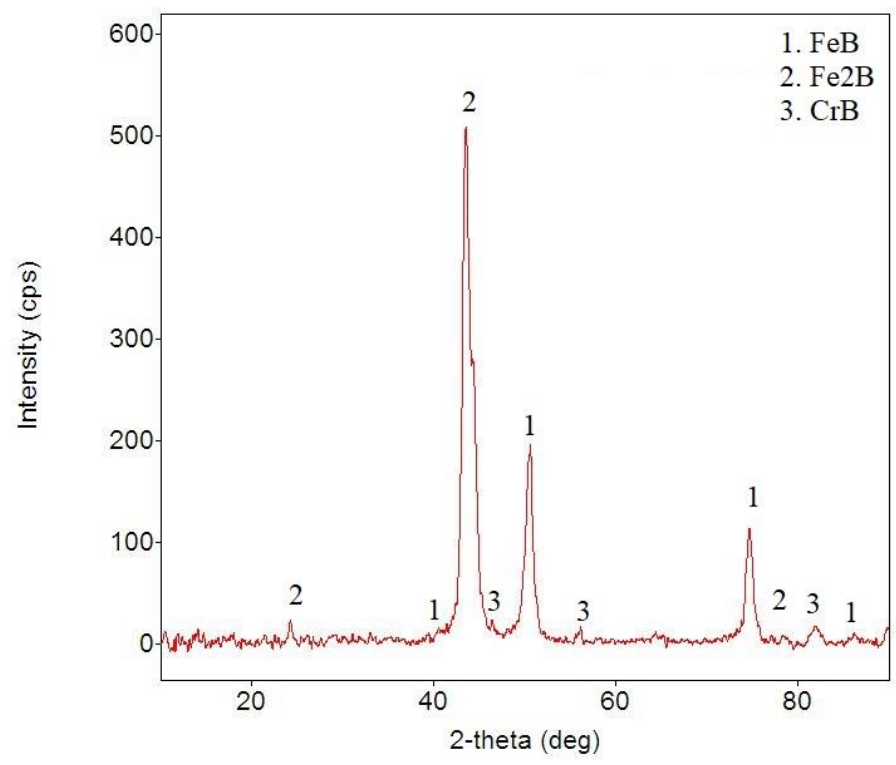

Figure 4: XRD result

In Figure 3b,c and d SEM picture of the coating zone and 3b SEM picture EDX result are given. The interface is evident in SEM pictures. The coating zone consists of dendtrite and eutectic structures. Dendtirit structures are observed to be mostly composed of cellular dendtritis and leafshaped dendtirites. As shown in Figure 3 SEM picture, with the high temperature occurring as a result 
of plasma arc temperature, diffusion transitions have occurred from the coating layer to the base material and from the base material to the coating layer [35]. Figure 4 presents the XRD analysis result. It was determined that $\mathrm{FeB}, \mathrm{Fe} 2 \mathrm{~B}$ and $\mathrm{CrB}$ compound phases are formed.

As a result of EDS analysis, wt. 7,271\% B, wt. 16,245\% Cr and wt. 76,484\% Fe elements were determined. According to these results, when Fe-B-Cr phase binary and ternary diagrams are examined in Figure 5 SEM-EDS, it is thought that $\mathrm{FeB}, \mathrm{Fe} 2 \mathrm{~B}$ and $\mathrm{CrB}$ compound phases are formed..

Homolová et al. stated that chromium has solubility in iron borides and iron in chromium borides, as a result of which $\mathrm{Cr} 2 \mathrm{~B}, \mathrm{Cr} 5 \mathrm{~B} 3, \mathrm{CrB}, \mathrm{Cr} 3 \mathrm{~B} 4, \mathrm{CrB} 2$ and $\mathrm{CrB} 4$, two iron borite $\mathrm{Fe} 2 \mathrm{~B}$ and $\mathrm{FeB}$ phase compounds are formed in the isothermal section study of the B-Cr-Fe triple phase system, [40]. In the study Gür et al. conducted, they stated that FeCrC TIC, SIC and B4C powders were melted as a result of PTA source energy after the solidification, as a result of EDS analysis in micro-structure EDS analysis, Fe,Cr,B,Si elements were formed, and in XRD results, FeB, Fe2B, Fe3(C, B), C3B6 phases applied for surface coating were formed [41]. As a result of this study, it is thought that there are probably the same phase compounds in their structures that have similar results with our EDS analysis.

As a result of the literature review, the authors match the phase compounds obtained after their analysis with the phase compounds obtained after XRD analysis in this study.

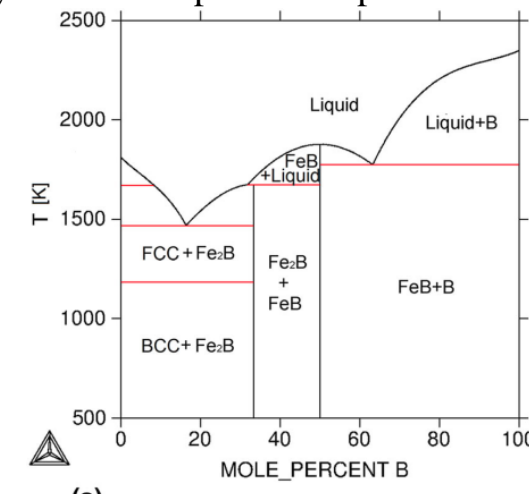

(a)

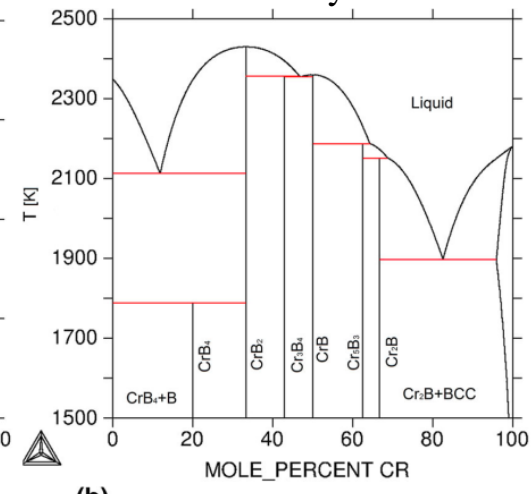

(b)

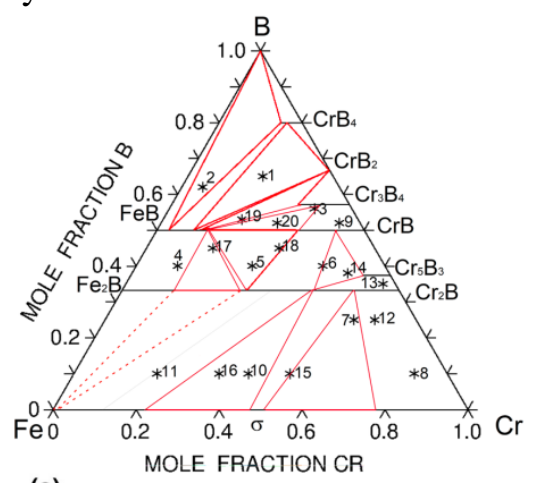

(c)

Figure 5: a) Fe-B binary, b) Fe-Cr binary c) Fe-B-Cr ternary phase diagram system [40].

\subsection{Surface Wear}

Other processes such as load, sliding distance, sliding time, lubrication status, material pair and coating methods applied in the wear of the materials are very important parameters. Some of these parameters are important when producing materials and some are important when making new processes such as coating on the produced material. The rest can be intervened in the wear test device. When these parameters are considered as a whole during the experiment, the important thing is the heat released during the friction, whether the tribo surface is formed, the friction coefficient value and the loss of mass or shape have changed [42]. According to the parameters specified in Table 1 on AISI $316 \mathrm{~L}$ stainless steel, the friction coefficients were measured during the wear tests of the materials coated with Boron. In Figure 6, the friction coefficient measured for $2250 \mathrm{~s}$ in abrasive wear experiments is given. 


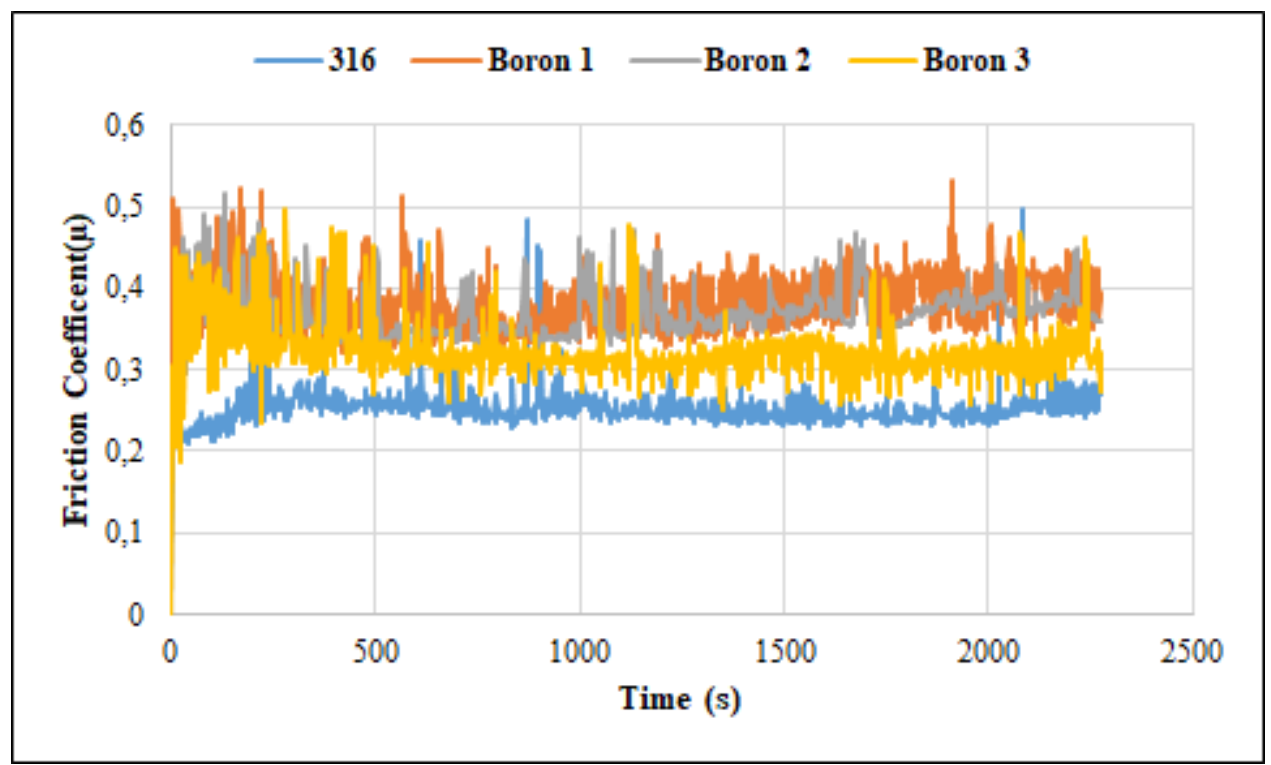

Figure 6: Graph of friction coefficient depending on time after wear

In abrasive wear experiments, it is seen that fluctuations occur while friction coefficient graph is obtained. In abrasive experiments, the fact that abrasive sanding has some certain pores and that it continuously ruptures materials from the surface of material has been the biggest factor in these fluctuations. When we look at the friction coefficient result of Boron 1 and Boron 2 samples, it is seen that it starts with 0,5 and continues in a stable direction with 0,4. Boron 3 sample, on the other hand, starts with 0,4 , and draws a lineer graphic with fixed 0,3 value. No difference is observed in values and graphics of friction coefficient obtained for different sliding distances. Accordingly, the average friction coefficients should be taken into account, especially when measuring the friction coefficient. Average friction coefficients of AISI $316 \mathrm{~L}$ material and materials coated with Boron1, Boron2 and Boron3 are obtained 0,$276 ; 0.381 ; 0.368$ and 0.324 , respectively. According to the average friction coefficient results, it is seen that the friction coefficient of the coated layers is higher than the substrate. Studies have reported that there are opinions that the friction coefficient increases or decreases depending on the wear parameters, and the reason for this is related to the formation of the tribo surface [43]. The tribo surface formed between the wear part and the sliding surface reduces the friction coefficient. In other words, when the load increases, the nominal contact area between the pin and the opposite surface increases, so the increase in the contact temperature leads to softening of the surface, thereby resulting in more sliding movement between the contact surfaces, thus reducing the coefficient of friction [44]. In Figure 7, mass losses due to shear distance are given in abrasive wear tests.

The mass loss graph obtained as a result of the wear analysis is given in Figure 7. As seen in the results, the highest mass loss was obtained from the AISI 316L stainless steel uncoated sample. It is seen that losses of approximately the same value occurred in the coated samples. Wear losses increased due to the sliding distance and this is an expected case. As shown in the graph in Figure 7, the lowest weight loss value at $250 \mathrm{~m}$ distance was obtained in Boron2 sample with approximately 5 $\mathrm{mg}$, while the highest value was obtained from uncoated AISI $316 \mathrm{~L}$ sample with a value of $13 \mathrm{mg}$. 
While the distance was about $1000 \mathrm{~m}$, the lowest weight loss value was obtained with Boron2 sample with approximately $25 \mathrm{mg}$, while it was found that there was a loss of approximately $45 \mathrm{mg}$ in the uncoated AISI 316 L sample.

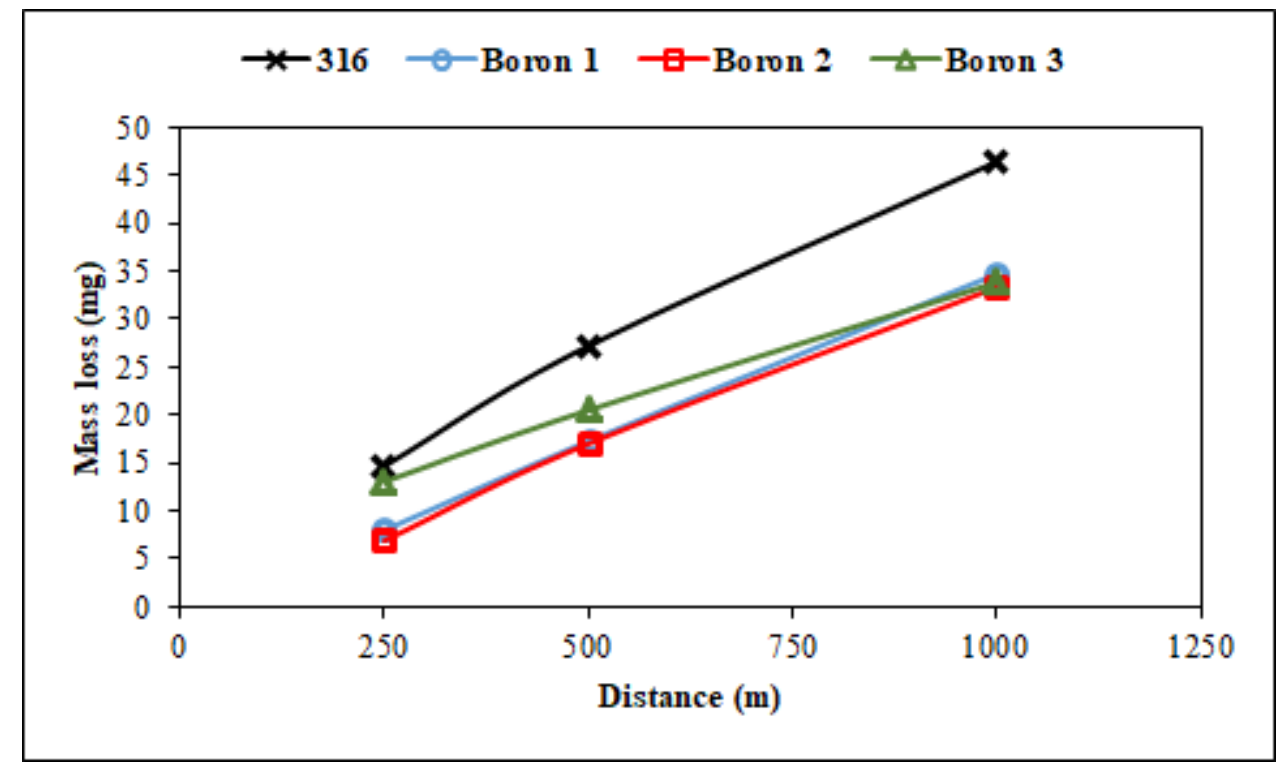

Figure 7: Mass loss graphic based on post-wear distance

According to these results, it is thought that hard boride structures formed as a result of coating with boron reduce the wear losses. An inverse proportion was found between mass loss and friction coefficient. The main reason for this inverse ratio is thought to be caused by hard boride layers formed on the surface. Kainz et al. stated that the addition of B, C or a combination of these during their surface treatment resulted in an increase in mechanical properties [45]. Çelik and Kilickap stated that hard particles also improved their tribological properties as they increased the hardness of the material [46]. With the results obtained, the surface losses of boron-coated samples were less than that of the uncoated sample. According to the results, it was determined that the coated samples had better abrasion resistance.

\section{Conclusions}

In this study, BORON coatability on AISI 316L steel surface was investigated by Plasma Arc Welding method. For this purpose, the following results have been achieved depending on the factors affecting the coating process, microstructure and abrasion results at different current values.

1. It has been determined that less mass loss has occurred in the coated samples compared to the uncoated sample as can be seen in the graph obtained.

2. 316 LL stainless steel with low hardness and weak abrasion resistance is thought to give more efficient results as a result of coating process with these materials.

3. From the microstructure analysis after coating, it is seen from the microstructure pictures that a good bond has been formed as a result of successful diffusion between coating layer in the materials coated with boron. 
4. It has been determined that dense dentric arms and eutectic structures have been formed between the coating samples, especially in the coating area, and the formed dentric structures have been perpendicular to the coating layer.

5. As a result of XRD analysis, it was determined that the microstructure consists of $\mathrm{CrB}, \mathrm{F} 2 \mathrm{~B}$ and $\mathrm{FeB}$ phase compounds.

\section{References}

[1] L. Bourithis L., G.D. Papadimitriou D.G.(2009). The effect of microstructure and wear conditions on the wear resistance of steel metal matrix composites fabricated with PTA alloying technique. Wear 266,1155-1164, doi:10.1016/j.wear.2009.03.032

[2] Yuan-Fu Liu, Zhi-Cheng Feng, Fei Pu, Zhi-Ying Xia, Guang-Bao Sun, Long-Hua Zhang, Chen-Xiao Shi, Zheng Zhang. (2018). Microstructure and dry-sliding wear properties of $\mathrm{TiC} / \mathrm{CaF} 2 / \gamma-\mathrm{Ni}$ selflubricating wear-resistant composite coating produced by co-axial powder feeding plasma transferred arc (PTA) cladding process. Surface \& Coatings Technology 345, 61-69, https://doi.org/10.1016/j.surfcoat.2018.04.003

[3] Fernandes F., Cavaleiro A., Loureiro A. (2012). Oxidation behavior of Ni-based coatings deposited by PTA on gray cast iron, Surface \& Coatings Technology 207, 196-203, doi:10.1016/j.surfcoat.2012.06.070

[4] Gür K.A., Kaya S. (2017) "PTA Kaplamalarda Abrasive Aşınma Davranışının Değerlendirilmesinde; Bir Taguchi Yaklaşımı" F.Ü. Mühendislik Bilimleri Dergisi 29(2) 195-202

[5] Buytoz, S., Yildirim, M. M., \& Eren, H. (2005). Microstructural and microhardness characteristics of gas tungsten are synthesized $\mathrm{Fe}-\mathrm{Cr}-\mathrm{C}$ coating on AISI 4340. Materials Letters, 59(6), 607-614.

[6] Islak, S., Kir, D., Buytoz, S., Özorak, C., Akkaş, M., Çaligülü, U., Yildirim, M. M. (2015). Yüksek Hizli Oksi Yakit İle Üretilen Wcco-Mo Esasli Kaplamalarin Mikroyapi Karakterizasyonu. Pamukkale University Journal of Engineering Sciences, 21(8).

[7] Lisowski, W., Hemmes, H., Jäger, D., Stöver, D., \& van Silfhout, A. (1992). Interaction between plasma sprayed $\mathrm{YBaCuO}$ and nimonic substrates. Applied surface science, 62(1-2), $13-20$

[8] Apay S., Gülenç B. (2013). Kobalt Bazlı Tozların PTA Yöntemiyle Düşük Karbonlu Çelik Üzerine Kaplanması ve Kaplama Bölgesinin İncelenmesi, Düzce Üniversitesi Bilim ve Teknoloji Dergisi 1.1: 77-87.

[9] Buytoz S., Orhan A., Gür K.A. and Caligulu U., (2013), Microstructural Properties of Fe-Cr-C and B4C Powder Alloy Coating on Stainless Steel by Plasma Transferred Arc Weld Surfacing, Arabian Jou. for Sci. and Eng.(ASJE), 38(8), 2197-2204 DOI:10.1007/s13369-013-0599-9 
[10] Hou, Q. Y., J. S. Gao, F. Zhou (2005). Microstructure and wear characteristics of cobalt-based alloy deposited by plasma transferred arc weld surfacing. Surface and Coatings Technology 194.2: 238-243.

[11] Bourithis, E., A. Tazedakis A., Papadimitriou G. (2002). A study on the surface treatment of "Calmax" tool steel by a plasma transferred arc (PTA) process. Journal of Materials Processing Technology 128.1: 169-177.

[12] Deuis, R. L., J. M. Yellup J.M., C. Subramanian C. (1998). Metal-matrix composite coatings by PTA surfacing. Composites science and technology 58.2: 299-309.

[13] Kucita P., Wang S.C., Li W.S., Cook R.B., Starink M.J. (2019). The effects of substrate dilution on the microstructure and wear resistance of PTA $\mathrm{Cu}-\mathrm{Al}-\mathrm{Fe}$ aluminium bronze coatings, Wear 440-441, 203102, https://doi.org/10.1016/j.wear.2019.203102

[14] Deng X., Zhang G., Wang T., Ren S., Shi Y., Bai Z., Cao Q. (2019). Microstructure and oxidation resistance of a multiphase Mo-Si-B ceramic coating on Mo substrates deposited by a plasma transferred arc process, Ceramics International 45, 415-423, https://doi.org/10.1016/j.ceramint.2018.09.182

[15] Dai W., Miao Y., Li J., Zheng Z., Zeng D., Huang Q. (2016). Investigation on morphology and micro-hardness characteristic of composite coatings reinforced by PTA copper alloying on nodular cast iron, Journal of Alloys and Compounds 689, 680-692, http://dx.doi.org/10.1016/j.jallcom.2016.08.007

[16] Deng X., Zhang G., Wang T., Ren S., Li Z., Song P., Shi Y. (2019). Characterization and oxidation resistance of B-modified Mo3Si coating on Mo substrate, Journal of Alloys and Compounds 807, 151693, https://doi.org/10.1016/j.jallcom.2019.151693

[17] A. K. Gur, C. Ozay, A. Orhan, S. Buytoz, U. Caligulu, and N. Yigitturk (2014) "Wear Properties of Fe-Cr-C and B4C Powder Coating on AISI 316 Stainless Steel Analyzed by the Taguchi Method, Materials Testing, 56(5), 393-398

[18] Gür K.A., (2013) "Investigating Wear Behavior By Using Taguchi Method FeCrCB4C Powder Alloys Coating By Plasma Transferred Arc Weld Surfacing", Materials Testing, 55(6): 462-467

[19] Hou Q.Y., He Y.Z., Zhang Q.A., Gao J.S. (2007). Influence of molybdenum on the microstructure and wear resistance of nickel-based alloy coating obtained by plasma transferred arc process." Materials and Design 28, 1982-1987

[20] Liu Y. F., Mu J. S., Xu X. Y., Yang S. Z. (2007). Microstructure and dry-sliding wear properties of TiC-reinforced composite coating prepared by plasma-transferred arc weldsurfacing process. Materials Science and Engineering: A, 458(1), 366-370.

[21] Bourithis L., Papaefthymiou S., Papadimitriou G.D. (2002). Plasma transferred arc boriding of a low carbon steel: microstructure and wear properties. Applied Surface Science 200.1: 203-218. 
[22] Iakovou R., Bourithis L., Papadimitriou G.(2002). Synthesis of boride coatings on steel using plasma transferred arc (PTA) process and its wear performance. Wear 252.11: 1007-1015.

[23] Buytoz S., Ulutan M., Kurt B. Islak S., Somunkıran İ. (2010). Plazma Transferli Ark Kaynak Yüzey İşlemiyle AISI 304 Paslanmaz Çelik Yüzeyine WC-Ni-B4C Kompozit Kaplamasının Mikroyapısal Karakteristiği. e-Journal of New World Sciences Academy, Volume: 5, Number: 1, Article Number: 1 A0063

[24] Tosun, G. (2011). 1010 Çeliğinin Ni-WC Tozları ile PTA Yöntemi Kullanılarak Kaplanması." 6 th International Advanced Technologies Symposium (IATS'11), 16-18 May 2011, Elazı̆g, Turkey 126-131

[25] Acevedo-D_avila J.L., Mu noz-Arroyo R., Hdz-García H.M., Martinez-Enriquez A.I., Alvarez-Vera M., Hern_andez-García F.A. (2017) Cobalt-based PTA coatings, effects of addition of TiC nanoparticles, Vacuum 143, 14-22, http://dx.doi.org/10.1016/j.vacuum.2017.05.033

[26] Mehmet AY M.G., Çelik N.O. (2019) Inspection of nickel-based boron carbide PTA coatings on AISI 4140 steel, Industrial Lubrication and Tribology, 71/4, 548-556, DOI 10.1108/ILT-06-2018-0224.

[27] Er Ü., Bilal Par B. (2004). Bor Yayınımıyla Yüzeyi Sertleştirilmiş AISI 1030 ve AISI1050 Çeliklerinin Abrazif Aşınma Dayanımlarının İncelenmesi. Osmangazi Üniversitesi Müh.Mim.Fak.Dergisi C.XVII, S.1.

[28] Uluköy A., Can Ç.A.. (2006). Çeliklerin Borlanmasi. Pamukkale Üniversitesi Mühendislik Bilimleri Dergisi, 12.2: 189-198.

[29] Ozbek I. (1999). Borlama Yöntemiyle AISI M50, AISI M52 Yüksek Hız Çeliklerinin ve AISI W1 Çeliğinin Yüzey Performansının Geliştirilmesi, Doktora Tezi, Sakarya Üniversitesi, Sakarya.

[30] Uluköy, A., Can Ç.A. (2006). Çeliklerin Borlanması. Pamukkale Üniversitesi,Mühendislik Bilimleri Dergisi, 12 (2) 189-198.

[31] S. Anil Kumar Sinha. (1991)."Boriding(Boronizing)." ASM International, ASM Handbook.4: 437-447.

[32] Diktaşlı E. (2014). Bazı Alaşımlı Çeliklerin Yükssek Sıcaklık Aşınma Davranışına Borlama İşleminin Etkisi. Yüksek Lisans Tezi, İstanbul Teknik Üniversitesi Fen Bilimleri Enstitüsü.

[33] Ünüvar F. (2013). Saf Kobaltın Borlama Özelliklerinin İncelenmesi, Yüksek Lisans Tezi, Süleyman Demirel Üniversitesi, Isparta.

[34] Çalık, A. (2005). Termokimyasal Borlama Yöntemleri ve Önemi. 4th International Advaced Technologies Symposium, 839-844, Konya. 
[35] Yildiz T., Gür K.A., (2011) Microstructural Characteristic Of N2 Shielding Gas in Coating FeCrC Composite to The Surface of AISI 1030 Steel with PTA Method, Archives of Metallurgy and Materials, 56, 723-729

[36] Bower F.T., Brody D. H., M. Flemings C.M. (1966). Measurements of Solute Redistribution in Dendritic Solidification. Transctions of the metallurgical society of aime, 624-volume 236.

[37] Choudhury A., Reuther K., Wesner E., August A., Nestler B., Rettenmayr M.. (2012). Comparison of phase-field and cellular automaton models for dendritic solidification in $\mathrm{Al}-\mathrm{Cu}$ alloy. Computational Materials Science 55, 263-268, doi:10.1016/j.commatsci.2011.12.019.

[38] Jabbari Behnam M.M., Davami P., Varahram N. (2010). Effect of cooling rate on microstructure and mechanical properties of gray cast iron. Materials Science and Engineering A 528 (2010) 583-588, doi:10.1016/j.msea.2010.09.087.

[39] Karagöz Ş., Rıdvan Yamanoğlu R., Atapek H. Ş. (2009). Atomize Tozlarda Katılaşma ve Mikroyapısal Karakterizasyon, Pamukkale Üniversitesi Mühendislik Bilimleri Dergisi, Cilt 15, Say1 3, Sayfa 309-316.

[40] Homolová V., Hiripová L. (2017). Experimental Investigation of Isothermal Section of the B-Cr-Fe Phase Diagram at 1353K, Hindawi Advances in Materials Science and Engineering Volume 2017, Article ID 2703986, 7 pages https://doi.org/10.1155/2017/2703986

[41] Gür K.A., Cengiz H.M., Taşkaya S.(2019). Mikroalaşımlı Hardox 400 Çelik Malzemenin plazma Transferli Ark Kaynak Yöntemiyle Alaşımlandırılması ve İncelenmesi. DÜMF Mühendislik Dergisi 10:3 (2019) : 969-979 , doi: 10.24012/dumf.529451.

[42] Demir E.M., Çelik H.Y. , Erol K. (2019). Effect of matrix material and orientation angle on tensile and tribological behavior of jute reinforced composites. Materials Testing, 61(8), 806812.

[43] Çelik H.Y., Demir E.M., Erol K., Kalkanlı A. (2020). Investigation of wear behavior of aged and non-aged $\mathrm{SiC}$-reinforced $\mathrm{AlSi} 7 \mathrm{Mg} 2$ metal matrix composites in dry sliding conditions. Journal of the Brazilian Society of Mechanical Sciences and Engineering, 42(1), Article Number 8, 1-9.

[44] Çelik H.Y, Seçilmiş K. (2017). Investigation of wear behaviours of Al matrix composites reinforced with different B4C rate produced by powder metallurgy method. Advanced Powder Technology, 28(9), 2218-2224, Doi: 10.1016/j.apt.2017.06.002.

[45] Christina Kainz, Nina Schalk, Michael Tkadletz, Christian Mitterer, Christoph Czettl (2019). The effect of B and C addition on microstructure and mechanical properties of TiN hard coatings grown by chemical vapor deposition. Thin Solid Films, 688, 137283, https://doi.org/10.1016/j.tsf.2019.05.002

[46] Çelik H.Y, ., Erol K (2019). Hardness and wear behaviours of Al matrix composites and hybrid composites reinforced with B4C and SiC. Powder Metallurgy and Metal Ceramics, 57(9-10), 613-622. 